Article

\title{
Isoliquiritigenin Pretreatment Induces Endoplasmic Reticulum Stress-Mediated Hormesis and Attenuates Cisplatin-Induced Oxidative Stress and Damage in LLC-PK1 Cells
}

\author{
Tania Gómez-Sierra, Omar Noel Medina-Campos, José D. Solano, María Elena Ibarra-Rubio \\ and José Pedraza-Chaverri *D
}

Departamento de Biología, Facultad de Química, Universidad Nacional Autónoma de México, CDMX 04510, Mexico; taniags@comunidad.unam.mx (T.G.-S.); mconoel@comunidad.unam.mx (O.N.M.-C.); jdsolanobecerra@comunidad.unam.mx (J.D.S.); meir@unam.mx (M.E.I.-R.)

* Correspondence: pedraza@unam.mx; Tel.: +52-555622-3878

Academic Editors: Paola Di Donato and Brigida Silvestri

Received: 25 August 2020; Accepted: 26 September 2020; Published: 27 September 2020

\begin{abstract}
Isoliquiritigenin (IsoLQ) is a flavonoid with antioxidant properties and inducer of endoplasmic reticulum (ER) stress. In vitro and in vivo studies show that ER stress-mediated hormesis is cytoprotective; therefore, natural antioxidants and ER stress inducers have been used to prevent renal injury. Oxidative stress and ER stress are some of the mechanisms of damage involved in cisplatin (CP)-induced nephrotoxicity. This study aims to explore whether IsoLQ pretreatment induces ER stress and produces hormesis to protect against CP-induced nephrotoxicity in Lilly Laboratories Cell-Porcine Kidney 1 (LLC-PK1) cells. During the first stage of this study, both IsoLQ protective concentration and pretreatment time against CP-induced toxicity were determined by cell viability. At the second stage, the effect of IsoLQ pretreatment on cell viability, ER stress, and oxidative stress were evaluated. IsoLQ pretreatment in CP-treated cells induces expression of glucose-related proteins 78 and $94 \mathrm{kDa}$ (GRP78 and GRP94, respectively), attenuates CP-induced cell death, decreases reactive oxygen species (ROS) production, and prevents the decrease in glutathione/glutathione disulfide (GSH/GSSG) ratio, free thiols levels, and glutathione reductase (GR) activity. These data suggest that IsoLQ pretreatment has a moderately protective effect on CP-induced toxicity in LLC-PK1 cells, through ER stress-mediated hormesis, as well as by the antioxidant properties of IsoLQ.
\end{abstract}

Keywords: isoliquiritigenin; cisplatin; nephrotoxicity; oxidative stress; ER stress; hormesis

\section{Introduction}

The flavonoid 4,2' $4^{\prime}$-trihydroxichalcone, also known as isoliquiritigenin (IsoLQ) (Figure 1), proceeds from the roots and rhizomes of licorice (Glycyrrizha glabra). It is used in Asia as an herbal medicine due to its anti-inflammatory, antimicrobial, antitumoral, and antioxidant properties [1-8]. Regarding its antioxidant activity, it has been reported that IsoLQ scavenges reactive oxygen species (ROS), such as the superoxide anion $\left(\mathrm{O}_{2}{ }^{\bullet-}\right)$, hydroxyl radical, hydrogen peroxide, and singlet oxygen [4,7], and induces phase II cytoprotective enzymes' expression $[9,10]$. In addition, IsoLQ has been used as an endoplasmic reticulum (ER) stress inducer in cancer cell lines to induce apoptosis [8,10-16] and also has cytoprotective effects in non-cancer cells, such as liver and kidney cells [1,4,9,16-18]. 


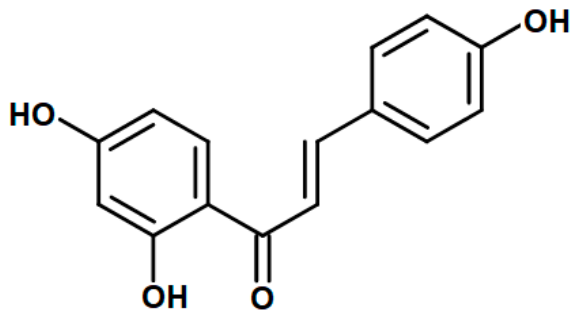

Figure 1. Chemical structure of isoliquiritigenin (IsoLQ).

On the other hand, cisplatin or cis-diaminodichloroplatin II (CP), is an antineoplastic drug approved by the United States Federal Drug Administration since 1978 used for the treatment of many cancers, such as head, neck, bladder, lung, stomach, uterus, and testicular. However, its application has been limited because $25-35 \%$ of treated patients develop kidney damage [19-23]. The mechanism of CP nephrotoxicity has been studied for the last forty years and binding to multiple targets such as deoxyribonucleic acid or glutathione (GSH) have been identified. Also, mechanisms such as oxidative stress, inflammation, mitochondrial dysfunction, and ER stress have been associated to kidney damage [19-22,24], and although the contribution of each pathway is not exactly known, oxidative stress plays a key role [19,24-26].

Under acute ER stress, glucose-related protein $78 \mathrm{kDa}$ (GRP78) and glucose-related protein $94 \mathrm{kDa}$ (GRP94) are released from the ER membrane and activate the unfolded protein response (UPR) to restore ER functions, such as protein synthesis and transport, protein folding, lipid and steroid synthesis, among others [27-31], in addition to the antioxidant response and autophagy [27,32-34], which maintain cellular homeostasis. However, if the ER stress is excessive or chronic and cannot be corrected, UPR signaling promotes apoptosis [29,31,35-39]. These different effects of UPR on cellular function have generated interest because of their similarity to those occurring in hormesis, a process usually referred to as a biological favorable response originated by low dose/concentration or short exposure to chemical/natural compounds or environmental factors [40-44]. However, a high dose/concentration or long exposure inhibits this favorable response [40,41,45-49]. It has been suggested that this biphasic dose-response could protect against more than one type of stress, and play a key role in the treatment of different pathologies [36,40,41,50-53].

Based on the knowledge of the main pathways involved in CP-induced nephrotoxicity, such as oxidative stress [19,21,22,25,54], apoptosis [20-22,25], mitochondrial dysfunction [20-22,25], kinases activation $[21,22,54]$, and ER stress [21,24,55], treatments with natural compounds have been implemented to prevent CP-induced nephrotoxicity [20,21,24,25,56-58]. However, it is necessary to explore more compounds and other targets less studied, such as ER stress, due to the complexity of cisplatin toxicity. Therefore, the aim of this study was to explore whether IsoLQ-induced ER stress produces a hormetic effect that protects against CP-induced nephrotoxicity in Lilly Laboratories Cell-Porcine Kidney 1 (LLC-PK1) cells.

\section{Results}

\subsection{First Stage}

\subsubsection{Estimation of Hormetic Zone of IsoLQ in CP-Induced Toxicity in LLC-PK1 Cells}

LLC-PK1 cells were treated with CP $(10-80 \mu \mathrm{M})$ for $24 \mathrm{~h}$. Figure 2 shows that $10 \mu \mathrm{M} \mathrm{CP}$ was not cytotoxic, whereas concentrations higher than $20 \mu \mathrm{M}$ induced cytotoxicity $(p<0.05)$ and the half-maximal $(50 \%)$ inhibitory concentration $\left(\mathrm{IC}_{50}\right)$ calculated was $29.4 \pm 3.8 \mu \mathrm{M}$. Figure 3 presents the typical inverted J-shaped hormetic relationship, where IsoLQ concentrations between 5 and $30 \mu \mathrm{M}$ attenuated CP-induced cell death $(p<0.05)$, whereas IsoLQ concentrations higher than $35 \mu \mathrm{M}$ increased CP-induced cell death $(p<0.05)$. 


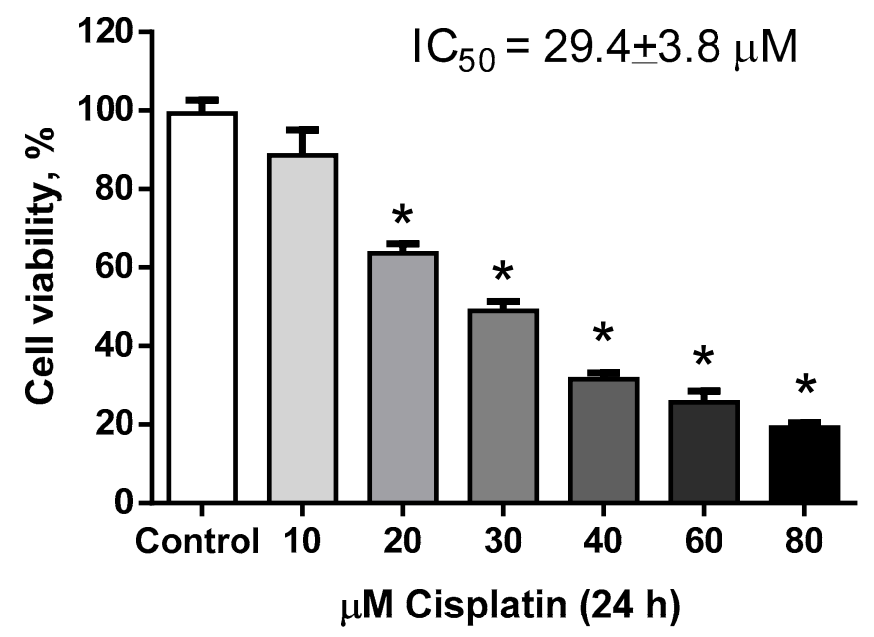

Figure 2. Cisplatin half-maximal $(50 \%)$ inhibitory concentration $\left(\mathrm{IC}_{50}\right)$ in $24 \mathrm{~h}$ treated Lilly Laboratories Cell-Porcine Kidney 1 (LLC-PK1) cells. Data are mean \pm standard error of the mean (SEM), $\mathrm{n}=3$. * $p<0.05$ vs. control (without cisplatin).

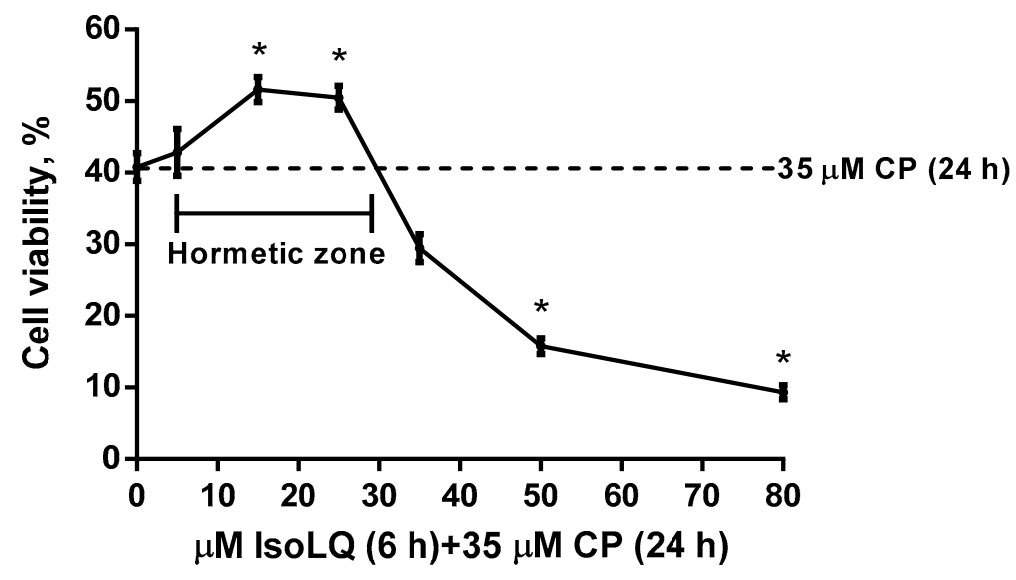

Figure 3. Hormetic dose-response curve of isoliquiritigenin (IsoLQ) in cisplatin (CP)-induced LLC-PK1 cell death. Data are mean $\pm \mathrm{SEM}, \mathrm{n}=3$. ${ }^{*} p<0.05$ vs. CP $24 \mathrm{~h}$.

2.1.2. Determination of IsoLQ Protective Concentration and Pretreatment Time against CP-Induced Toxicity in LLC-PK1 Cells

According to the data shown in Figure 2, $40 \mu \mathrm{M}$ CP caused $\sim 66 \%$ of cell death $(p<0.05)$, while Figure 3 shows that 15 and $25 \mu \mathrm{M}$ IsoLQ attenuated CP-induced decrease on cell viability $(p<0.05)$. Therefore, these two concentrations were used to determine the IsoLQ pretreatment time that could have a protective effect against CP-induced toxicity in LLC-PK1 cells. Cell viability results indicate that 6 and $8 \mathrm{~h}$ pretreatment with 15 and $25 \mu \mathrm{M}$ IsoLQ promoted cytoprotective effects against $40 \mu \mathrm{M} \mathrm{CP}(p<0.05)$ (Figure 4). 
A)

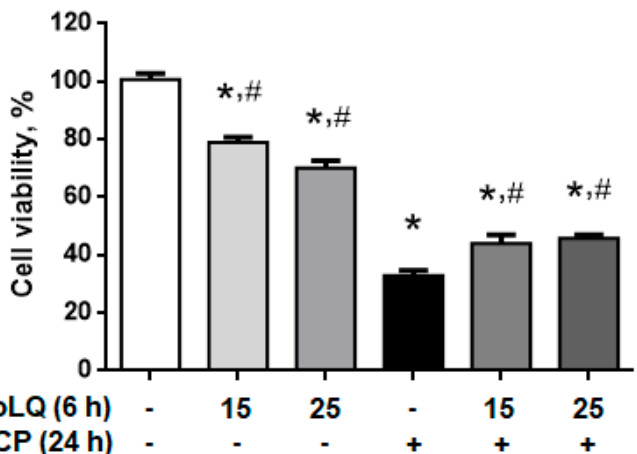

B)

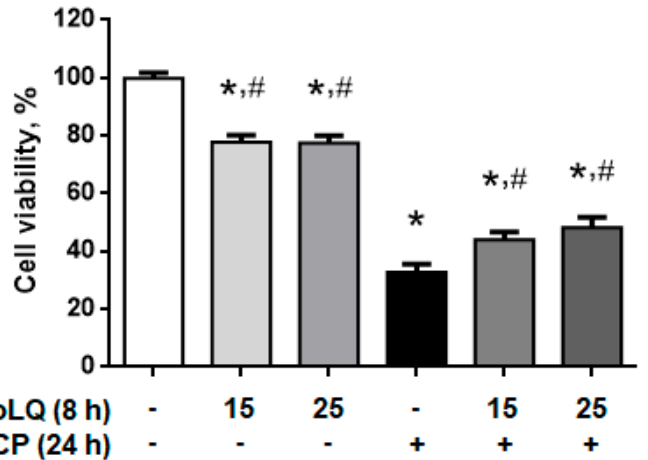

Figure 4. Isoliquiritigenin (IsoLQ) pretreatment attenuated cell viability decrease in cisplatin (CP)-induced toxicity. (A) $6 \mathrm{~h}$ IsoLQ pretreatment, (B) $8 \mathrm{~h}$ IsoLQ pretreatment. Data are mean \pm SEM, $\mathrm{n}=3$. ${ }^{*} p<0.05$ vs. control (without IsoLQ and CP), ${ }^{\#} p<0.05$ vs. CP.

\subsubsection{Pretreatment of IsoLQ Induces ER Stress}

According to the data shown in Figure 4, 15 and $25 \mu \mathrm{M}$ IsoLQ pretreatment attenuated CP-induced cell death $(p<0.05)$, so cells were treated with the highest concentration of IsoLQ $(25 \mu \mathrm{M})$ to evaluate ER stress. Figure 5 shows that GRP94 and GRP78 increased at 4 and $6 \mathrm{~h}(p<0.05)$ respectively, after pretreatment with $25 \mu \mathrm{M}$ IsoLQ, and remained increased at $24 \mathrm{~h}$.
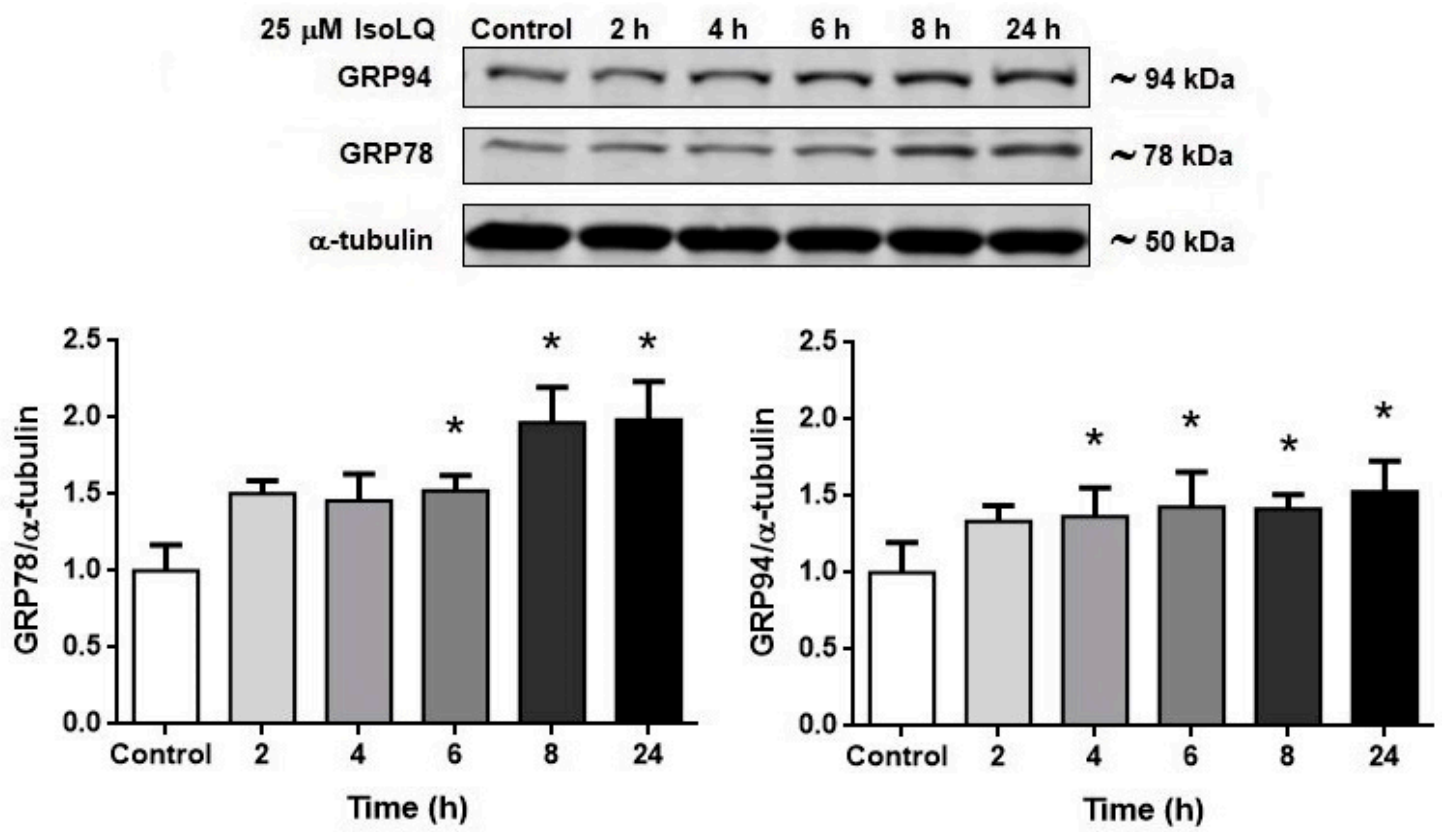

Figure 5. $25 \mu \mathrm{M}$ isoliquiritigenin (IsoLQ) induced endoplasmic reticulum (ER) stress in LLC-PK1 cells. Glucose-related protein 78 kDa (GRP78), glucose-related protein 94 kDa (GRP94). Data are mean \pm SEM, $\mathrm{n}=3-4 .{ }^{*} p<0.05$ vs. control (without IsoLQ).

\subsection{Second Stage}

\subsubsection{IsoLQ Pretreatment Enhanced ER Stress in CP-Induced Nephrotoxicity in LLC-PK1 Cells}

Based on cell viability results as well as protein levels of GRP78 and GRP94 obtained from first-stage experiments, the experimental protocol was designed as follows: cells were pretreated with $25 \mu \mathrm{M}$ IsoLQ for $8 \mathrm{~h}$ (the highest effects on cell viability and GRP78 and GRP94 expression were observed in these conditions) and subsequently with $40 \mu \mathrm{M} \mathrm{CP}$ (the highest $\mathrm{CP}$ concentration evaluated) for a time-course study. After pretreatment of LLC-PK1 cells with $25 \mu \mathrm{M}$ IsoLQ for $8 \mathrm{~h}$ and exposure to $40 \mu \mathrm{M}$ 
CP for 16 and 24 h, GRP78 and GRP94 expression increased $(p<0.05)$ (Figure 6A). This increase was higher than that under IsoLQ treatment or with CP alone (Figures 5 and 6B, respectively). In addition, the expression of the eukaryotic initiation factor 2 alpha (p-eIF2 $\alpha$ ) did not change (data not shown).

A)
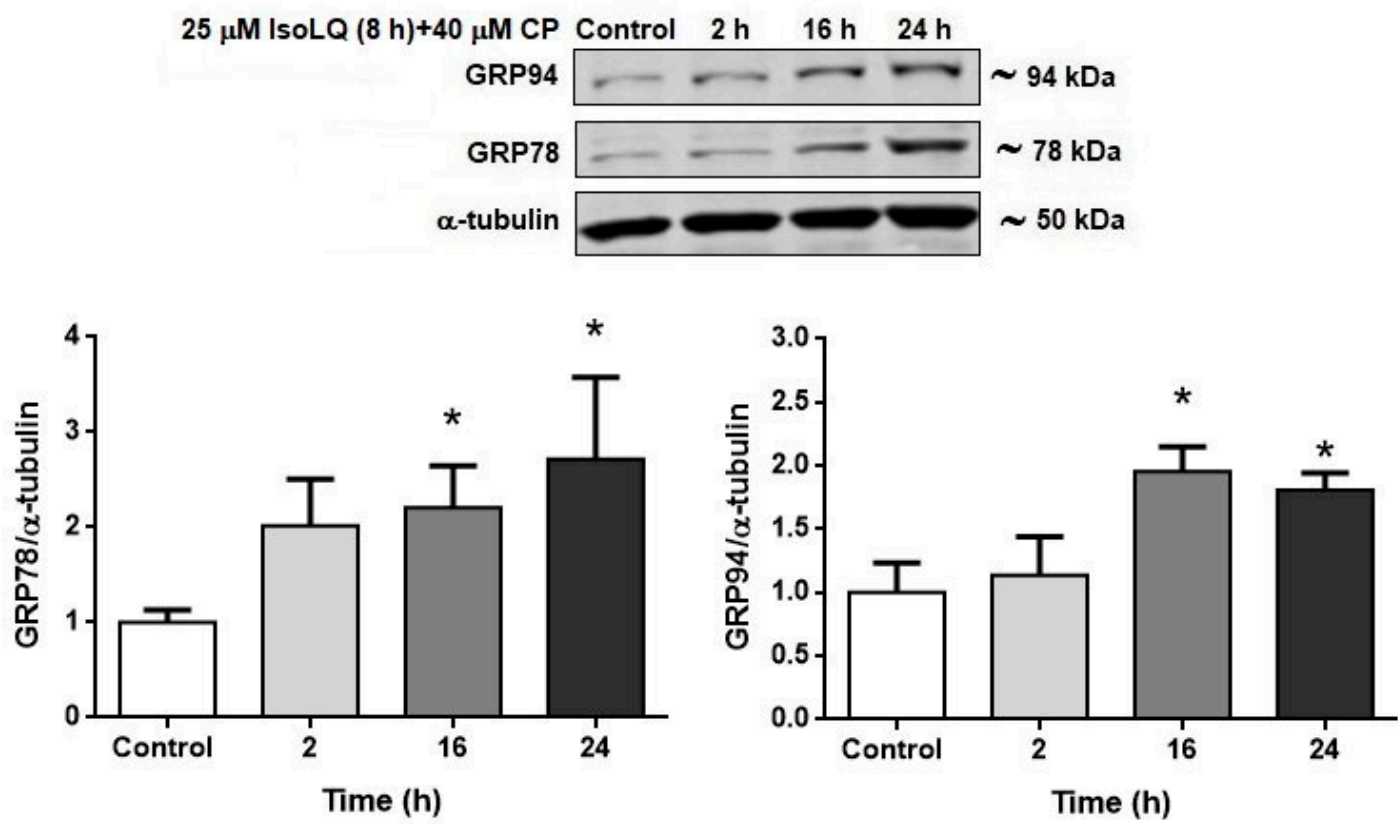

B)
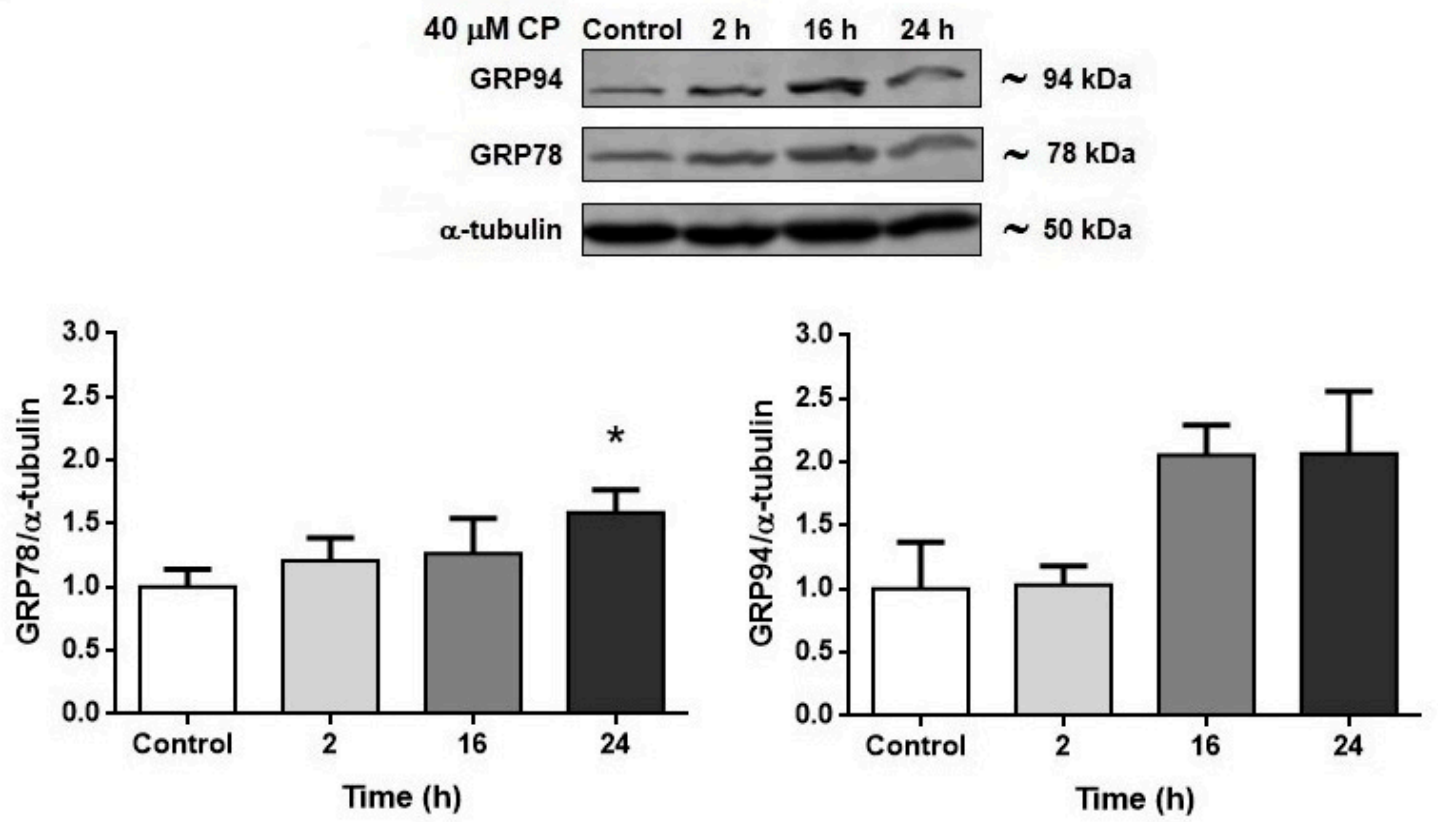

Figure 6. Endoplasmic reticulum (ER) stress in LLC-PK1 cells. (A) $25 \mu \mathrm{M}$ isoliquiritigenin (IsoLQ, $8 \mathrm{~h}$ ) pretreatment $+40 \mu \mathrm{M}$ cisplatin (CP) treatment. (B) $40 \mu \mathrm{M} \mathrm{CP}$ treatment. Glucose-related protein $78 \mathrm{kDa}$ (GRP78), glucose-related protein $94 \mathrm{kDa}$ (GRP94). Data are mean $\pm \mathrm{SEM}, \mathrm{n}=3 .{ }^{*} p<0.05 \mathrm{vs}$. control (without IsoLQ and CP).

\subsubsection{IsoLQ-Induced Hormesis Attenuates Oxidative Stress in CP-Treated LLC-PK1 Cells}

LLC-PK1 cells were pretreated with $25 \mu \mathrm{M}$ IsoLQ for $8 \mathrm{~h}$ and then with $40 \mu \mathrm{M} \mathrm{CP}$ for 16 and $24 \mathrm{~h}$, as described for the second stage of the experimental design. $25 \mu \mathrm{M}$ IsoLQ pretreatment decreased ROS production by $\sim 37 \%$ and $\sim 26 \%$ after exposure to $40 \mu \mathrm{M} \mathrm{CP}$ for 16 and $24 \mathrm{~h}(p<0.05)$ respectively, 
and attenuated the decrease in GSH/glutathione disulfide (GSSG) ratio, free thiols, and glutathione reductase (GR) activity $24 \mathrm{~h}$ after CP treatment $(p<0.05)$ (Table 1$)$.

Table 1. Effect of isoliquiritigenin (IsoLQ)-induced hormesis on oxidative stress in LLC-PK1 cells after 16 and $24 \mathrm{~h}$ of cisplatin $(\mathrm{CP})$ treatment.

\begin{tabular}{|c|c|c|c|c|c|c|}
\hline \multirow{2}{*}{$\begin{array}{c}\text { Groups } \\
\text { Time CP Treatment }\end{array}$} & \multirow{2}{*}{$\begin{array}{c}\text { Control } \\
0 \mathrm{~h}\end{array}$} & \multirow{2}{*}{$\begin{array}{c}25 \mu \mathrm{M} \text { IsoLQ } \\
(8 \mathrm{~h})\end{array}$} & \multicolumn{2}{|c|}{$40 \mu \mathrm{M} \mathrm{CP}$} & \multicolumn{2}{|c|}{$25 \mu \mathrm{M}$ IsoLQ $(8 \mathrm{~h})+40 \mu \mathrm{M} \mathrm{CP}$} \\
\hline & & & $16 \mathrm{~h}$ & $24 \mathrm{~h}$ & $16 \mathrm{~h}$ & $24 \mathrm{~h}$ \\
\hline GSH/GSSG & $5.92 \pm 0.35$ & ND & $1.67 \pm 0.19 *$ & $1.49 \pm 0.16^{*}$ & $2.14 \pm 0.13^{*}$ & $3.22 \pm 0.44^{*}, \#$ \\
\hline Free thiols (nmol/mg protein) & $143.9 \pm 2.9$ & $138.1 \pm 13.6^{\#}$ & $115.1 \pm 3.6$ & $85.1 \pm 4.6^{*}$ & $148.9 \pm 27.1$ & $204.9 \pm 28.7^{\#}$ \\
\hline GR activity (U/mg protein) & $0.015 \pm 0.001$ & $0.014 \pm 0.001$ \# & $0.010 \pm 0.001 *$ & $0.006 \pm 0.001 *$ & $0.011 \pm 0.001$ * & $0.014 \pm 0.001$ \# \\
\hline
\end{tabular}

ROS, reactive oxygen species; GSH/GSSG, glutathione/glutathione disulfide ratio; GR, glutathione reductase. Data are mean $\pm \mathrm{SEM}, \mathrm{n}=3$. ${ }^{*} p<0.05$ vs. control (without IsoLQ and CP), ${ }^{* *} p<0.05$ vs. CP $16 \mathrm{~h},{ }^{*} p<0.05$ vs. CP $24 \mathrm{~h}$. ND, not determined.

Nitric Oxide Synthase (NOS) is the Source of ROS Production in LLC-PK1 Cells Pretreated with IsoLQ and Exposed to CP

In order to determine intracellular ROS sources, we used diphenyleneiodonium chloride (DPI), an inhibitor of nicotinamide adenine dinucleotide phosphate hydrogen (NADPH) oxidase (NOX), or N-nitro-L-arginine methyl ester (L-NAME), an inhibitor of NOS. DPI did not decrease ROS production in any of the groups of treated cells, whereas L-NAME decreased ROS production at $16 \mathrm{~h}$ in IsoLQ + CP-treated cells to similar levels as the control group $(p<0.05)$. This effect remained until $24 \mathrm{~h}(p<0.05)$ (Figure 7); whereas in CP-treated cells, ROS production decreased only at $16 \mathrm{~h}(p<0.05)$.
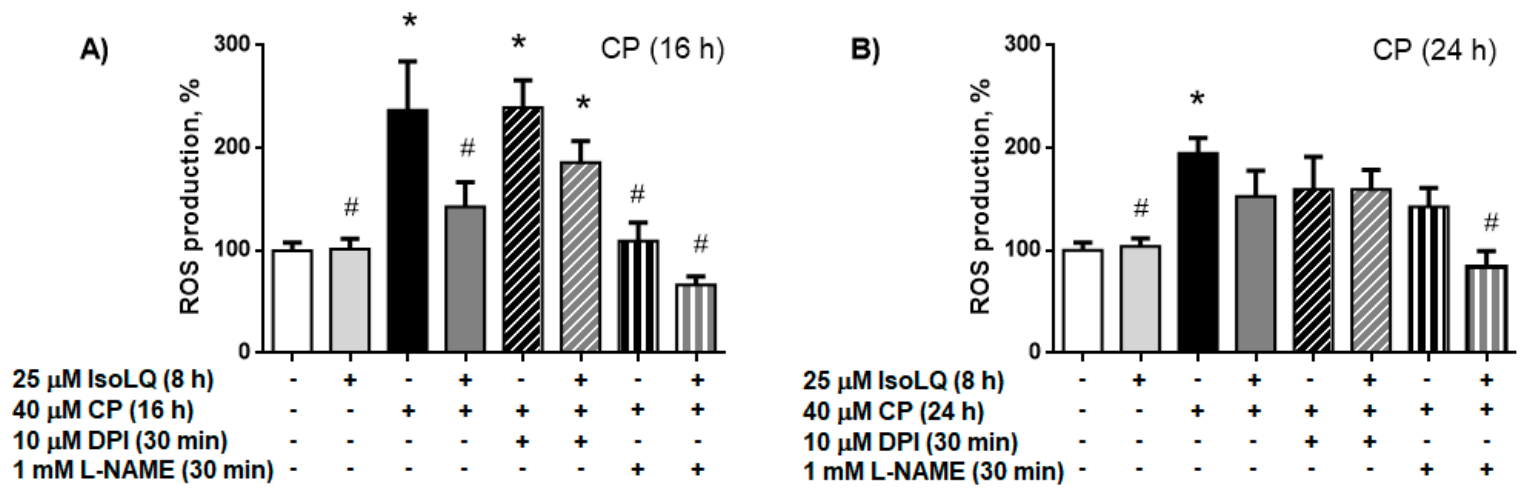

Figure 7. Nitric oxide synthase (NOS), but not nicotinamide adenine dinucleotide phosphate hydrogen (NADPH) oxidase (NOX), is the source of reactive oxygen species (ROS) production in LLC-PK1 cells pretreated with $25 \mu \mathrm{M}$ isoliquiritigenin (IsoLQ, $8 \mathrm{~h}$ ) and subsequently with $40 \mu \mathrm{M}$ cisplatin (CP). Diphenyleneiodonium chloride (DPI), N-nitro-L-arginine methyl ester (L-NAME). (A) $16 \mathrm{~h} \mathrm{CP}$ treatment. (B) $24 \mathrm{~h} \mathrm{CP}$ treatment. Data are mean $\pm \mathrm{SEM}, \mathrm{n}=3 .{ }^{*} p<0.05$ vs. control (without IsoLQ and $\mathrm{CP}),{ }^{\#} p<0.05$ vs. CP.

\section{Discussion}

IsoLQ is a flavonoid with anti-inflammatory, antitumoral, and antioxidant properties [1-7,16,59] that exerts protective effects in liver and kidney cells $[3,4,9,16-18]$. In addition, it has been demonstrated that IsoLQ does not interfere with CP antineoplastic activity [16]. The effect of IsoLQ on cell viability in CP-induced nephrotoxicity was a biphasic dose-response: low IsoLQ concentrations attenuated the decrease on cell viability, but high IsoLQ concentrations inhibited it. This effect is known as hormesis, a term that refers to a biological favorable cellular response $[40,47-50,60]$. The IsoLQ + CP dose-response curve showed an inverted J-shaped hormetic effect and this biphasic curve has an interval called the hormetic zone where the beneficial effects are evident (Figure 3) [45,47-49]. The low-dose stimulation reflects the capacity of the cells to distribute biological resources that help to defend the 
organism from a wide range of stressor agents, such as $\mathrm{CP}$, and this adaptive mechanism includes stress protein responses that reduce the damage more effectively than the response induced only by exposure to the stressor $[40,41,46,47]$. Therefore, hormesis is more than simply a dose-response relationship, it is a quantitative and temporal manifestation of reparative processes that is adaptive in nature, such as UPR elicited by ER stress [42,43,46,47,50,60,61].

Data obtained show that $25 \mu \mathrm{M}$ IsoLQ pretreatment induced ER stress and also attenuated $40 \mu \mathrm{M}$ CP-induced cell death in LLC-PK1 cells. The increase in the expression of the chaperones GRP78 and GRP94 indicates the occurrence of ER stress and suggests the activation of UPR $[27,29,37,62-65]$. The early induction of ER stress could play a key role in cell survival, because ER stress induced by IsoLQ pretreatment generated a hormetic effect to activate adaptive responses such as UPR, that protects against higher stress levels as occurs in CP-induced nephrotoxicity. In in vitro and in vivo models of kidney diseases, like renal ischemia-reperfusion or exposure to cytotoxic compounds, the a priori induction of ER stress with pharmacological or natural compounds generates tolerance against these insults (hypoxia, oxidative stress) in order to inhibit the apoptotic cell death [37,52,53,62,66-69].

On the other hand, oxidative stress is also characteristic in CP-induced nephrotoxicity and is an important factor in the development and progression of other associated damage mechanisms, such as mitochondrial dysfunction, inflammation, and ER stress [19-22,25,26,54,70]. ROS are generated naturally and regulate cell functions [71,72]. However, excessive quantities of ROS can result in damage to proteins, modifying their function and disrupting ER homeostasis [27,32,34,73]. ROS overproduction can be sensed by the ER, which is highly sensitive to changes in ROS levels through redox sensors, such as, for example, the thiol groups of cysteines [33,70,74-77], causing misfolded protein accumulation and consequently increasing ROS production, which leads to a vicious cycle able to activate UPR, generate chronic stress, and induce apoptosis [32-34,70,72]. Moreover, ROS overproduction causes a decrease in the GSH/GSSG ratio and in antioxidant enzyme levels, whilst oxidizing lipids, DNA, and proteins [19-22,25,26]. In our experimental model, ROS production could be associated to NOS activity and consequently to overproduction of $\mathrm{O}_{2}{ }^{\bullet-}$ that enhances oxidative stress. However, IsoLQ can attenuate this oxidative imbalance due to its ROS scavenging capacity [4,7]. In CP-induced nephrotoxicity, the decrease in the GSH/GSSG ratio is characteristic due to the formation of GSH-CP adducts. The positively charged species of CP (their active forms) have a great affinity for thiol groups $[20,22,25,78,79]$ and consequently, there is an alteration in the activity of enzymes related to GSH metabolism $[19,26,78]$. In addition, the decrease in GSH could be associated with the formation of disulfide bonds among misfolded proteins in a coupled reaction with the protein disulfide isomerase and ER oxidoreductase 1 [73,80-83].

Interestingly, ER stress induction is also associated with an increase in GSH biosynthesis in order to form disulfide bonds between proteins and recycle unfolded proteins. This effect could explain the increase in free thiols, such as GSH, in cells pretreated with IsoLQ [33,82]. Moreover, it has been described that ER stress increases the activity of antioxidant enzymes such as GR, glutathione peroxidase, and glutathione S-transferase [33,63,82]. Probably, augmented GR activity in cells pretreated with IsoLQ was due to this effect, since IsoLQ is also a bifunctional antioxidant able to induce expression of phase II detoxifying enzymes through nuclear factor erythroid 2 (Nrf2) transcriptional regulation $[9,10]$. Under ER stress, protein kinase ribonucleic acid (RNA)-activated-like ER kinase (PERK), one the of the signaling pathways of UPR, directly phosphorylates Nrf2, causing Nrf2 to dissociates from its negative regulator (Kelch-like erythroid-derived cap-n-collar homology-(ECH-)associated protein 1); after which, Nrf2 translocates to the nucleus, leading the transcription of genes that encode phase II detoxifying enzymes that maintain redox homeostasis and may contribute to cell survival [84-86]. In addition, eIF $2 \alpha$ is another target of the PERK signaling pathway $[27,29,63,65]$. Even though the data on p-eIF2 $\alpha$ expression are inconclusive (data not shown), it is possible that the PERK pathway has become activated. Nevertheless, studies on the role of UPR proteins are required to describe and understand the mechanisms involved in the hormetic effect produced by IsoLQ in this experimental model. In summary, Figure 8 shows a possible mechanism of the protective effect of IsoLQ against 
CP-induced nephrotoxicity in LLC-PK1 cells. We derived our assumptions from the main observations found in this study.

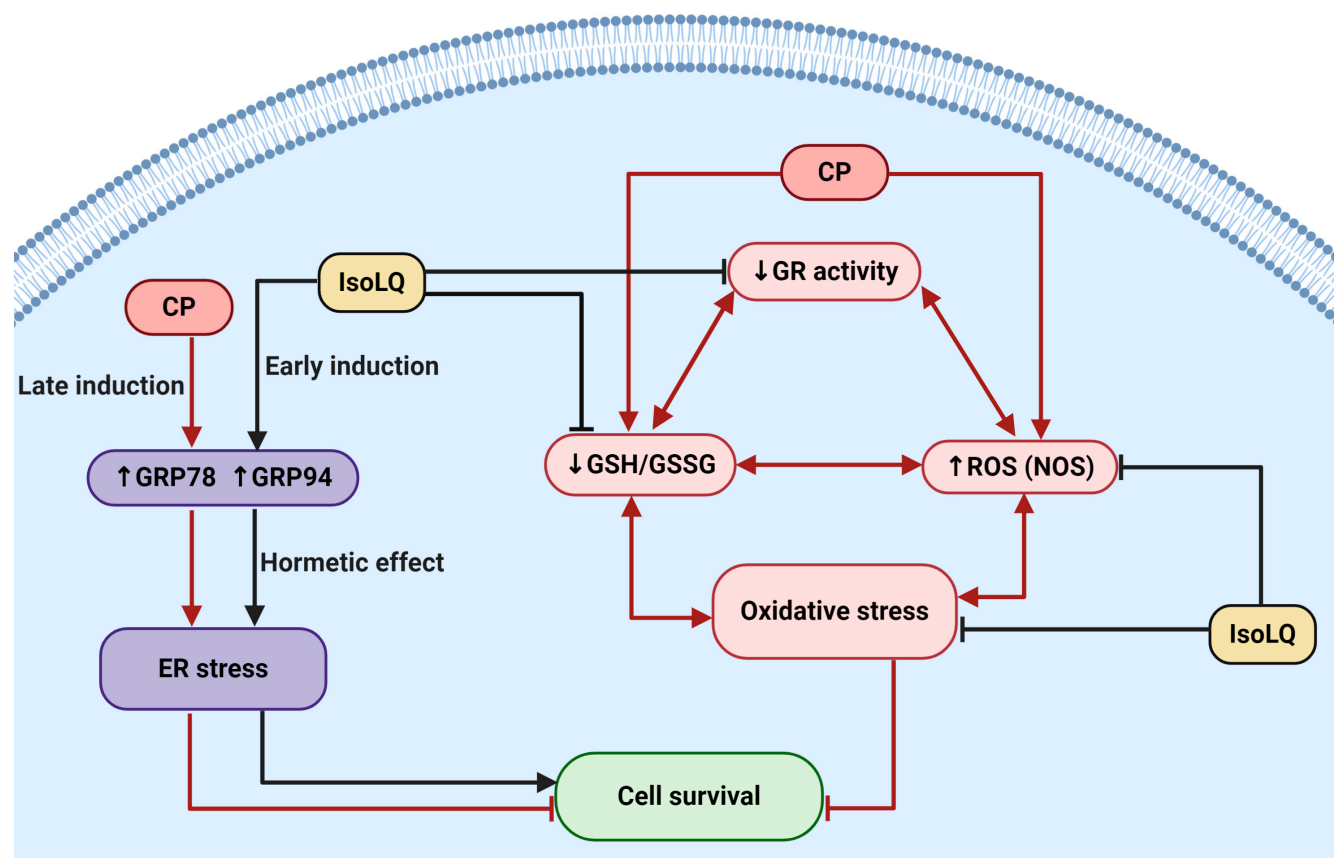

Figure 8. Mechanisms involved in the protective effect of isoliquiritigenin (IsoLQ) against cisplatin (CP)-induced damage in LLC-PK1 cells. Pretreatment with IsoLQ increased the expression of glucose-regulated protein 78 (GRP78) and glucose-regulated protein 94 (GRP94), markers of endoplasmic reticulum (ER)-stress. The generated hormetic effect induces a decrease in reactive oxygen species (ROS) production, associated to nitric oxide synthase (NOS) activity, as well as the attenuation in the reduction of glutathione/glutathione disulfide (GSH/GSSG) ratio and glutathione reductase (GR) activity. These combined effects, in addition to the antioxidant properties of IsoLQ, attenuated oxidative stress. Figure was created with Biorender.com.

\section{Materials and Methods}

\subsection{Reagents}

LLC-PK1 cells were obtained from the American Type Culture Collection (ATCC, Rockville, MD, USA). IsoLQ was purchased from AK Scientific (Union City, NJ, USA). Bovine serum albumin, CP, 1-chloro-2,4-dinitrobenzene, dimethyl sulfoxide, DPI, 5,5'-dithiobis-(2-nitrobenzoic acid), fluorescein diacetate (FDA), glycerophosphate, GSH, GSSG, GR, L-NAME, NADPH, 4-nonylphenyl-polyethylene glycol (NP-40), protease inhibitor cocktail, sodium deoxycholate, sodium dodecyl sulfate (SDS), sodium fluoride $(\mathrm{NaF})$, sodium pyrophosphate $\left(\mathrm{Na}_{4} \mathrm{P}_{2} \mathrm{O}_{7}\right)$, sodium orthovanadate $\left(\mathrm{Na}_{3} \mathrm{VO}_{4}\right)$, sulfosalicylic acid, triethanolamine, Tris-hydrochloride (Tris-HCl), trypan blue, triton X-100, tween 20, 2-vinylpirydine, mouse anti- $\alpha$-tubulin (cat. T9026) antibodies, and rabbit anti-GRP94 (cat. G4420) antibodies were from Sigma Aldrich Co. (St. Louis, MO, USA). Dipotassium hydrogen orthophosphate, ethylenediaminetetraacetic acid disodium salt (EDTA), potassium chloride, potassium dihydrogen orthophosphate, sodium chloride $(\mathrm{NaCl})$, sodium bicarbonate $\left(\mathrm{NaHCO}_{3}\right)$, and sodium phosphate dibasic were from J.T. Baker (Xalostoc, Edo. Mex, Mex). Bradford reagent was from Bio-Rad (Hercules, CA, USA). Dulbecco's Modified Eagle's Medium (DMEM), fetal bovine serum (FBS), and penicillin/streptomycin were from Biowest (Riverside, MO, USA). TrypLE Express was from Thermo Fisher Scientific (Waltham, MA, USA). Dichlorodihydrofluorescein diacetate $\left(\mathrm{H}_{2} \mathrm{DCFDA}\right)$ was from Molecular Probes (Eugene, OR, USA). Mouse anti-GRP78 (cat. SC-3768) antibodies were from Santa Cruz Biotechnology Inc. (Dallas, TX, USA). Fluorescent secondary antibodies anti-rabbit 800CW 
and anti-mouse 680RD were from LI-COR Biosciences (Lincoln, NE, USA). All the other chemicals and reagents used were of analytical grade and commercially available.

\subsection{Cell Culture}

LLC-PK1 cells are a proximal tubule cell line derived from porcine kidneys, widely used in experimental models $[9,25,53,87]$. LLC-PK1 cells were cultured in DMEM supplemented with 10\% FBS, $0.33 \% \mathrm{NaHCO}_{3}, 100 \mathrm{U} / \mathrm{mL}$ penicillin, and $50 \mathrm{U} / \mathrm{mL}$ streptomycin under a humidified atmosphere of $5 \% \mathrm{CO}_{2}$ at $37^{\circ} \mathrm{C}$. The cells were sub-cultured with TrypLE Express upon reaching $90 \%$ confluence. LLC-PK1 cells passage numbers 8 to 33 were used.

\subsection{Experimental Design}

\subsubsection{First Stage}

The aim of the first stage set of experiments was to determine the potential IsoLQ protective concentration and pretreatment time against CP-induced toxicity in LLC-PK1 cell culture. Cells were treated with $\mathrm{CP}(10-80 \mu \mathrm{M})$ for $24 \mathrm{~h}$ to calculate the $\mathrm{IC}_{50}$. Additionally, cells were pretreated with IsoLQ $(5-80 \mu \mathrm{M})$ for $6 \mathrm{~h}$ and later incubated with one concentration higher than the $\mathrm{IC}_{50}$ of $\mathrm{CP}(35 \mu \mathrm{M})$ for $24 \mathrm{~h}$ to evaluate the potentially hormetic dose-response curve for cell viability. Finally, two IsoLQ concentrations within the hormetic zone $(15$ and $25 \mu \mathrm{M})$ and one concentration higher than the $\mathrm{IC}_{50}$ of $\mathrm{CP}(40 \mu \mathrm{M})$ were selected to test the putative protective effect by IsoLQ on cell viability.

On the other hand, cells were pretreated with $25 \mu \mathrm{M}$ IsoLQ (highest concentration within the hormetic zone) in a time-course study (2-24 h) to evaluate the expression of GRP78 and GRP94.

\subsubsection{Second Stage}

Based on the first stage results, LLC-PK1 cells were pretreated with $25 \mu \mathrm{M}$ IsoLQ for $8 \mathrm{~h}$ and subsequently incubated, in a time-course study, with $40 \mu \mathrm{M} \mathrm{CP}$ to evaluate ER stress $(2,16$, and $24 \mathrm{~h})$ and oxidative stress (16 and $24 \mathrm{~h}$ ). The experimental design is summarized in Figure 9.

\subsection{Cell Viability}

Subsequently after treatments, DMEM was removed and cells were washed with phosphatebuffered saline (PBS) followed by the addition of $12 \mu \mathrm{M}$ FDA and incubation for $5 \mathrm{~min}$ at $37^{\circ} \mathrm{C}$ in darkness [88]. Fluorescence was determined by a microplate reader at excitation and emission wavelengths of 485 and $520 \mathrm{~nm}$, respectively. The results are expressed as the percentage of the control (without treatments).

\subsection{Extraction of Total Fractions of Proteins for Western Blot}

LLC-PK1 cells were lysed with radioimmunoprecipitation assay (RIPA) buffer (50 mM Tris-HCl, pH 7.4, $150 \mathrm{mM} \mathrm{NaCl}, 1 \mathrm{mM}$ EDTA, 0.5\% sodium deoxycholate, $1 \%$ NP-40, 0.1\% SDS, $25 \mathrm{mM} \mathrm{NaF}$, $1 \mathrm{mM} \mathrm{Na}_{4} \mathrm{P}_{2} \mathrm{O}_{7}, 1 \mathrm{mM} \mathrm{Na}_{3} \mathrm{VO}_{4}, 0.5 \mathrm{mM}$ glycerophosphate, and protease inhibitor cocktail) for one hour at $4{ }^{\circ} \mathrm{C}$. Lysates were centrifuged at $12,000 \times g$ during $10 \mathrm{~min}$ at $4{ }^{\circ} \mathrm{C}$ and the supernatant was collected and stored at $-70^{\circ} \mathrm{C}$ until use. Total protein content was determined by the Bradford assay [89]. 


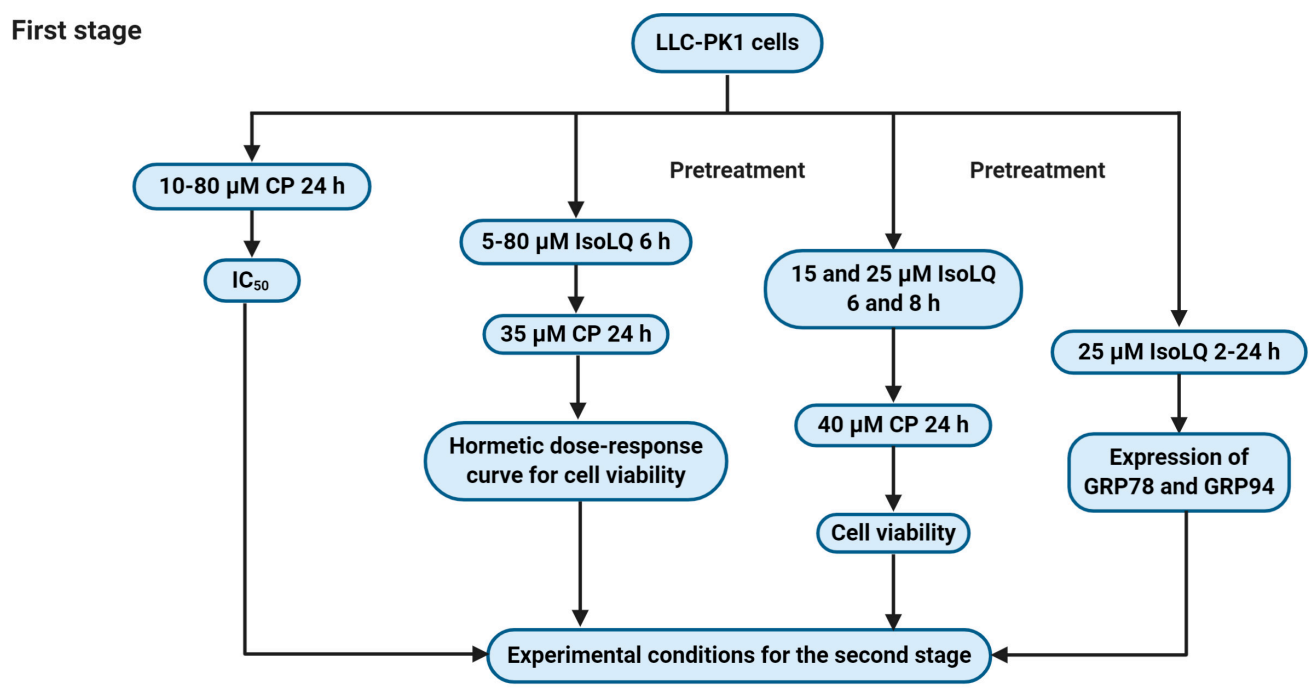

Second stage

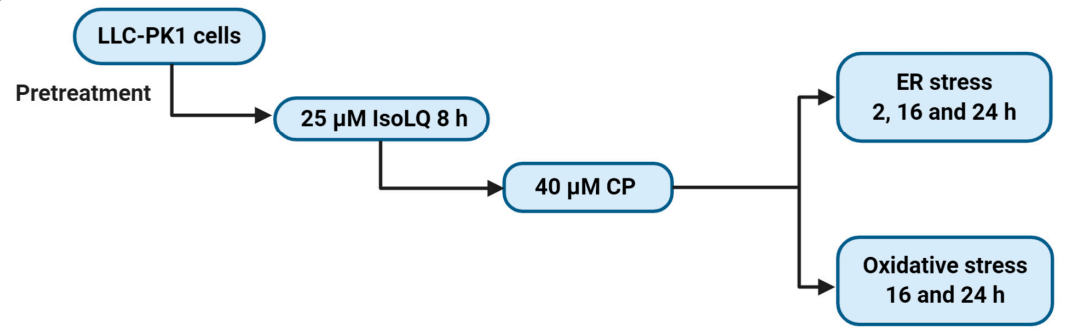

Figure 9. Scheme of the experimental design. CP, cisplatin; IsoLQ, isoliquiritigenin; GRP78, glucoseregulated protein $78 \mathrm{kDa}$; GRP94, glucose-regulated protein $94 \mathrm{kDa}$; ER, endoplasmic reticulum. Figure was created with Biorender.com.

\subsection{ER Stress Evaluation}

Western Blot Analysis

Proteins were separated by SDS-polyacrylamide gel electrophoresis (PAGE) and transferred to polyvinylidene fluoride membranes, which were blocked for one hour with $5 \%$ skimmed milk or bovine serum albumin. Membranes were left incubating overnight at $4{ }^{\circ} \mathrm{C}$ with the appropriate primary antibodies against GRP78 (1:1000), GRP94 (1:1000), and $\alpha$-tubulin (1:8000). Subsequently, membranes were washed and incubated with the appropriate secondary antibodies for two hours. The proteins of interest were detected with the LI-COR Odyssey Sa Infrared Imaging System (Lincoln, NE, USA). Image analysis was performed with Image Studio Lite Software version 5.2.

\subsection{Oxidative Stress Evaluation}

\subsubsection{Measurement of ROS Production}

After the second stage cell treatments, DMEM was removed and cells were washed with PBS followed by incubation with $10 \mu \mathrm{M} \mathrm{H}_{2}$ DCFDA for $30 \mathrm{~min}$ at $37^{\circ} \mathrm{C}$ in the darkness. Fluorescence intensity was visualized and determined in a Cytation 5 Cell Imaging Reader (Biotek Instruments, Inc., Winooski, VT, USA) at excitation and emission wavelengths of 485 and $520 \mathrm{~nm}$, respectively. Relative fluorescence intensity of treated cells was expressed as a percentage of the control (without treatments).

In order to determine the intracellular ROS sources, LLC-PK1 cells were pretreated with IsoLQ for $8 \mathrm{~h}$, then with CP for 16 or $24 \mathrm{~h}$. At $30 \mathrm{~min}$ before the end of the CP treatments, the NOX inhibitor $10 \mu \mathrm{M}$ DPI and the NOS inhibitor $1 \mathrm{mM}$ L-NAME, were added separately to the cell cultures. Finally, the growth medium was removed, and the measurement of ROS was carried out as described above. 


\subsubsection{Measurement of GSH/GSSG Ratio}

The redox status, expressed as the GSH/GSSG ratio, was determined following a method previously described [90].

\subsubsection{Free Thiols Levels}

Free thiols were determined following a method previously described [91]. Total protein content was determined by the Bradford assay [89]. Results are expressed as nmol/mg protein.

\subsubsection{GR Activity}

Activity of GR was determined by measuring the disappearance of NADPH at $340 \mathrm{~nm}$. Total protein content was determined by the Bradford assay [89]. Results are expressed as U/mg protein, where U equals one $\mu \mathrm{mol}$ of oxidized NADPH per minute [92].

\subsection{Statistical Analysis}

The results are expressed as mean \pm standard error of the mean (SEM). Statistical analysis was performed for each determination using the software Graph-Pad Prism 6.0 (San Diego, CA, USA) comparing the mean values through a one-way analysis of variance, followed by the Tukey's multiple comparison test. For the time-course studies of Western blot, a Student's $t$-test was carried out with respect to the control. A $p$-value $<0.05$ was considered significant.

\section{Conclusions}

The mechanism of cisplatin toxicity is complex and involves many cellular targets, some of which are less studied, such as ER stress, which could have cytoprotective or cytotoxic effects. However, if ER stress is induced early with natural compounds such as IsoLQ, the effects could be beneficial because the cell adapts to stress, distributing biological resources to help defend the organism from a wide range of stressor agents, such as CP. However, to describe the mechanisms involved in this specific hormetic effect, it is necessary to study and explore each UPR pathway activated in this particular experimental model.

In conclusion, our results suggest that pretreatment with IsoLQ induces the expression of GRP78 and GRP94, consequently inducing ER stress-mediated hormesis and ameliorating oxidative stress, both of which have a moderately protective effect against CP-induced nephrotoxicity in LLC-PK1 cells. This study provides another strategy or perspective to prevent cisplatin-induced toxicity, which can be applied to the study of other reticulum stress-inducing compounds.

Author Contributions: Conceptualization, T.G.-S., O.N.M.-C. and J.P.-C.; methodology, formal analysis, investigation, and data curation, T.G.-S.; writing-original draft preparation, T.G.-S., O.N.M.-C. and J.P.-C.; writing-review and editing, T.G.-S., O.N.M.-C., J.D.S., M.E.I.-R. and J.P.-C.; supervision and funding acquisition, J.P.-C. All authors have read and agreed to the published version of the manuscript.

Funding: This research was funded by (1) Consejo Nacional de Ciencia y Tecnología (CONACYT, A1-S-7495), (2) Programa de Apoyo a Proyectos de Investigación e Innovación Tecnológica (PAPIIT, IN202219), Dirección General de Asuntos del Personal Académico, Universidad Nacional Autónoma de México (UNAM), and (3) Programa de Apoyo a la Investigación y al Posgrado (PAIP, 5000-9105).

Acknowledgments: T.G.-S. is a PhD student who received a scholarship from CONACYT-México and would like to thank Posgrado en Ciencias Biológicas, UNAM. This article is a requirement for obtaining the Doctor of Science degree of the Programa de Posgrado de Ciencias Biológicas, UNAM. We thank Elena Martínez-Klimova for English and style corrections to the manuscript.

Conflicts of Interest: The authors declare no conflict of interest. 


\section{References}

1. Chen, C.; Huang, S.; Chen, C.L.; Su, S.B.; Fang, D.D. Isoliquiritigenin Inhibits Ovarian Cancer Metastasis by Reversing Epithelial-to-Mesenchymal Transition. Molecules 2019, 24, 3725. [CrossRef] [PubMed]

2. Kim, J.Y.; Park, S.J.; Yun, K.J.; Cho, Y.W.; Park, H.J.; Lee, K.T. Isoliquiritigenin isolated from the roots of Glycyrrhiza uralensis inhibits LPS-induced iNOS and COX-2 expression via the attenuation of NF- $\mathrm{kB}$ in RAW 264.7 macrophages. Eur. J. Pharmacol. 2008, 584, 175-184. [CrossRef] [PubMed]

3. Lee, Y.; Chin, Y.W.; Bae, J.K.; Seo, J.; Choi, Y. Pharmacokinetics of Isoliquiritigenin and Its Metabolites in Rats: Low Bioavailability Is Primarily Due to the Hepatic and Intestinal Metabolism. Planta Med. 2013, 79, 1656-1665. [CrossRef] [PubMed]

4. Ramalingam, M.; Kim, H.; Lee, Y.; Lee, Y.I. Phytochemical and Pharmacological Role of Liquiritigenin and Isoliquiritigenin From Radix Glycyrrhizae in Human Health and Disease Models. Front. Aging Neurosci. 2018, 10, 348. [CrossRef]

5. Takahashi, T.; Takasuka, N.; Iigo, M.; Baba, M.; Nishino, H.; Tsuda, H.; Okuyama, T. Isoliquiritigenin, a flavonoid from licorice, reduces prostaglandin E2 and nitric oxide, causes apoptosis, and suppresses aberrant crypt foci development. Cancer Sci. 2004, 95, 448-453. [CrossRef]

6. Tanemoto, R.; Okuyama, T.; Matsuo, H.; Okumura, T.; Ikeya, Y.; Nishizawa, M. The constituents of licorice (Glycyrrhiza uralensis) differentially suppress nitric oxide production in interleukin-1 $\beta$-treated hepatocytes. Biochem. Biophys. Rep. 2015, 2, 153-159. [CrossRef]

7. Wang, A.; Lu, Y.; Shi, P.; Zhang, H. Hydroxyl and hydroperoxyl radicals scavenging by isoliquiritigenin and liquiritigenin: A quantum chemical study. Struct. Chem. 2017, 28, 1181-1186. [CrossRef]

8. Zhao, H.; Yuan, X.; Li, D.; Chen, H.; Jiang, J.; Wang, Z.; Sun, X.; Zheng, Q. Isoliquiritigen Enhances the Antitumour Activity and Decreases the Genotoxic Effect of Cyclophosphamide. Molecules 2013, 18, 8786-8798. [CrossRef]

9. Moreno-Londoño, A.P.; Bello-Alvarez, C.; Pedraza-Chaverri, J. Isoliquiritigenin pretreatment attenuates cisplatin induced proximal tubular cells (LLC-PK1) death and enhances the toxicity induced by this drug in bladder cancer T24 cell line. Food Chem. Toxicol. 2017, 109, 143-154. [CrossRef]

10. Orlikova, B.; Tasdemir, D.; Golais, F.; Dicato, M.; Diederich, M. Dietary chalcones with chemopreventive and chemotherapeutic potential. Genes Nutr. 2011, 6, 125-147. [CrossRef]

11. Chen, H.Y.; Huang, T.C.; Shieh, T.M.; Wu, C.H.; Lin, L.C.; Hsia, S.M. Isoliquiritigenin Induces Autophagy and Inhibits Ovarian Cancer Cell Growth. IJMS 2017, 18, 2025. [CrossRef] [PubMed]

12. Hu, F.W.; Yu, C.C.; Hsieh, P.L.; Liao, Y.W.; Lu, M.Y.; Chu, P.M. Targeting oral cancer stemness and chemoresistance by isoliquiritigenin-mediated GRP78 regulation. Oncotarget 2017, 8, 93912-93923. [CrossRef] [PubMed]

13. Kanazawa, M.; Satomi, Y.; Mizutani, Y.; Ukimura, O.; Kawauchi, A.; Sakai, T.; Baba, M.; Okuyama, T.; Nishino, H.; Miki, T. Isoliquiritigenin Inhibits the Growth of Prostate Cancer. Eur. Urol. 2003, 43, 580-586. [CrossRef]

14. Si, L.; Yang, X.; Yan, X.; Wang, Y.; Zheng, Q. Isoliquiritigenin induces apoptosis of human bladder cancer T24 cells via a cyclin-dependent kinase-independent mechanism. Oncol. Lett. 2017, 14, 241-249. [CrossRef]

15. Zhou, G.S.; Song, L.J.; Yang, B. Isoliquiritigenin inhibits proliferation and induces apoptosis of U87 human glioma cells in vitro. Mol. Med. Rep. 2013, 7, 531-536. [CrossRef]

16. Lee, C.K.; Son, S.H.; Park, K.K.; Park, J.H.Y.; Lim, S.S.; Chung, W.Y. Isoliquiritigenin Inhibits Tumor Growth and Protects the Kidney and Liver Against Chemotherapy-Induced Toxicity in a Mouse Xenograft Model of Colon Carcinoma. J. Pharm. Sci 2008, 106, 444-451. [CrossRef]

17. Peng, F.; Du, Q.; Peng, C.; Wang, N.; Tang, H.; Xie, X.; Shen, J.; Chen, J. A Review: The Pharmacology of Isoliquiritigenin: A Review: The Pharmacology of ISL. Phytother. Res. 2015, 29, 969-977. [CrossRef]

18. Wang, Z.F.; Liu, J.; Yang, Y.A.; Zhu, H.L. A Review: The Anti-inflammatory, Anticancer and Antibacterial Properties of Four Kinds of Licorice Flavonoids Isolated from Licorice. CMC 2020, 27, 1997-2011. [CrossRef]

19. Chirino, Y.I.; Pedraza-Chaverri, J. Role of oxidative and nitrosative stress in cisplatin-induced nephrotoxicity. Exp. Toxicol. Pathol. 2009, 61, 223-242. [CrossRef]

20. dos Santos, N.A.G.; Carvalho Rodrigues, M.A.; Martins, N.M.; dos Santos, A.C. Cisplatin-induced nephrotoxicity and targets of nephroprotection: An update. Arch. Toxicol. 2012, 86, 1233-1250. [CrossRef] 
21. Manohar, S.; Leung, N. Cisplatin nephrotoxicity: A review of the literature. J. Nephrol. 2018, 31, 15-25. [CrossRef] [PubMed]

22. Miller, R.P.; Tadagavadi, R.K.; Ramesh, G.; Reeves, W.B. Mechanisms of Cisplatin Nephrotoxicity. Toxins 2010, 2, 2490-2518. [CrossRef] [PubMed]

23. Sancho-Martínez, S.M.; Prieto-García, L.; Prieto, M.; López-Novoa, J.M.; López-Hernández, F.J. Subcellular targets of cisplatin cytotoxicity: An integrated view. Pharmacol. Ther. 2012, 136, 35-55. [CrossRef] [PubMed]

24. Gómez-Sierra, T.; Eugenio-Pérez, D.; Sánchez-Chinchillas, A.; Pedraza-Chaverri, J. Role of food-derived antioxidants against cisplatin induced-nephrotoxicity. Food Chem. Toxicol. 2018, 120, 230-242. [CrossRef] [PubMed]

25. Pabla, N.; Dong, Z. Cisplatin nephrotoxicity: Mechanisms and renoprotective strategies. Kidney Int. 2008, 73, 994-1007. [CrossRef] [PubMed]

26. Peres, L.A.B.; da Cunha Júnior, A.D. Acute nephrotoxicity of cisplatin: Molecular mechanisms. J. Bras. Nefrol. 2013, 35, 332-340. [CrossRef]

27. Almanza, A.; Carlesso, A.; Chintha, C.; Creedican, S.; Doultsinos, D.; Leuzzi, B.; Luís, A.; McCarthy, N.; Montibeller, L.; More, S.; et al. Endoplasmic reticulum stress signaling-from basic mechanisms to clinical applications. FEBS J. 2019, 286, 241-278. [CrossRef]

28. Braakman, I.; Hebert, D.N. Protein Folding in the Endoplasmic Reticulum. Cold Spring Harb. Perspect. Biol. 2013, 5, a013201. [CrossRef] [PubMed]

29. Schönthal, A.H. Endoplasmic Reticulum Stress: Its Role in Disease and Novel Prospects for Therapy. Scientifica 2012, 2012, 857516. [CrossRef]

30. Schwarz, D.S.; Blower, M.D. The endoplasmic reticulum: Structure, function and response to cellular signaling. Cell. Mol. Life Sci. 2016, 73, 79-94. [CrossRef] [PubMed]

31. Wang, Q.; Groenendyk, J.; Michalak, M. Glycoprotein Quality Control and Endoplasmic Reticulum Stress. Molecules 2015, 20, 13689-13704. [CrossRef] [PubMed]

32. Malhotra, J.D.; Kaufman, R.J. Endoplasmic Reticulum Stress and Oxidative Stress: A Vicious Cycle or a Double-Edged Sword? Antioxid. Redox Signal. 2007, 9, 2277-2294. [CrossRef]

33. Ozgur, R.; Uzilday, B.; Iwata, Y.; Koizumi, N.; Turkan, I. Interplay between the unfolded protein response and reactive oxygen species: A dynamic duo. J. Exp. Bot. 2018, 69, 3333-3345. [CrossRef] [PubMed]

34. Reyes-Fermín, L.M.; Aparicio-Trejo, O.E.; Avila-Rojas, S.H.; Gómez-Sierra, T.; Martínez-Klimova, E.; Pedraza-Chaverri, J. Natural antioxidants' effects on endoplasmic reticulum stress-related diseases. Food Chem. Toxicol. 2020, 138, 111229. [CrossRef] [PubMed]

35. Boyce, M.; Yuan, J. Cellular response to endoplasmic reticulum stress: A matter of life or death. Cell Death Differ. 2006, 13, 363-373. [CrossRef]

36. Inagi, R.; Kumagai, T.; Nishi, H.; Kawakami, T.; Miyata, T.; Fujita, T.; Nangaku, M. Preconditioning with Endoplasmic Reticulum Stress Ameliorates Mesangioproliferative Glomerulonephritis. JASN 2008, 19, 915-922. [CrossRef]

37. Kitamura, M. Endoplasmic reticulum stress and unfolded protein response in renal pathophysiology: Janus faces. Am. J. Physiol.-Ren. Physiol. 2008, 295, F323-F334. [CrossRef]

38. Shi, S.; Tan, P.; Yan, B.; Gao, R.; Zhao, J.; Wang, J.; Guo, J.; Li, N.; Ma, Z. ER stress and autophagy are involved in the apoptosis induced by cisplatin in human lung cancer cells. Oncol. Rep. 2016, 35, 2606-2614. [CrossRef]

39. Song, S.; Tan, J.; Miao, Y.; Li, M.; Zhang, Q. Crosstalk of autophagy and apoptosis: Involvement of the dual role of autophagy under ER stress. J. Cell Physiol. 2017, 232, 2977-2984. [CrossRef]

40. Mattson, M.P. Hormesis defined. Ageing Res. Rev. 2008, 7, 1-7. [CrossRef]

41. Zimmermann, A.; Bauer, M.; Kroemer, G.; Madeo, F.; Carmona-Gutierrez, D. When less is more: Hormesis against stress and disease. MIC 2014, 1, 150-153. [CrossRef] [PubMed]

42. Mollereau, B. Establishing Links between Endoplasmic Reticulum-Mediated Hormesis and Cancer. Mol. Cell. Biol. 2013, 33, 2372-2374. [CrossRef] [PubMed]

43. Mollereau, B.; Manié, S.; Napoletano, F. Getting the better of ER stress. J. Cell Commun. Signal. 2014, 8, 311-321. [CrossRef] [PubMed]

44. Marques, F.Z.; Markus, M.A.; Morris, B.J. Hormesis as a pro-healthy aging intervention in human beings? Dose Response 2009, 8, 28-33. [CrossRef] [PubMed] 
45. Breithaupt, H. Fierce creatures: Zoonoses, diseases that jump from animals to humans, are a growing health problem around the world. Understanding their causes and their effects on humans have therefore become an important topic for global public health. EMBO Rep. 2003, 4, 921-924. [CrossRef] [PubMed]

46. Calabrese, E.J. Hormesis: Why it is important to toxicology and toxicologists. Environ. Toxicol. Chem. 2008, 27, 1451. [CrossRef]

47. Calabrese, E.J.; Baldwin, L.A. The Dose Determines the Stimulation (and Poison): Development of a Chemical Hormesis Database. Int. J. Toxicol. 1997, 16, 545-559. [CrossRef]

48. Calabrese, E.J.; Baldwin, L.A. U-Shaped Dose-Responses in Biology, Toxicology, and Public Health. Annu. Rev. Public Health 2001, 22, 15-33. [CrossRef]

49. Lushchak, V.I. Dissection of the Hormetic Curve: Analysis of Components and Mechanisms. Dose-Response 2014, 12. [CrossRef]

50. Calabrese, E.J.; Mattson, M.P. How does hormesis impact biology, toxicology, and medicine? NPJ Aging Mech. Dis. 2017, 3, 13. [CrossRef]

51. Foufelle, F.; Fromenty, B. Role of endoplasmic reticulum stress in drug-induced toxicity. Pharm. Res. Perspect 2016, 4, e00211. [CrossRef] [PubMed]

52. Inagi, R. Endoplasmic reticulum stress as a progression factor for kidney injury. Curr. Opin. Pharmacol. 2010, 10, 156-165. [CrossRef] [PubMed]

53. Peyrou, M.; Cribb, A.E. Effect of endoplasmic reticulum stress preconditioning on cytotoxicity of clinically relevant nephrotoxins in renal cell lines. Toxicol. In Vitro 2007, 21, 878-886. [CrossRef] [PubMed]

54. Dasari, S.; Bernard Tchounwou, P. Cisplatin in cancer therapy: Molecular mechanisms of action. Eur. J. Pharmacol. 2014, 740, 364-378. [CrossRef] [PubMed]

55. Tian, J.; Liu, R.; Qu, Q. Role of endoplasmic reticulum stress on cisplatin resistance in ovarian carcinoma. Oncol. Lett. 2017, 13, 1437-1443. [CrossRef]

56. Mohan, I.K.; Khan, M.; Shobha, J.C.; Naidu, M.U.R.; Prayag, A.; Kuppusamy, P.; Kutala, V.K. Protection against cisplatin-induced nephrotoxicity by Spirulina in rats. Cancer Chemother. Pharm. 2006, 58, 802-808. [CrossRef]

57. Zou, P.; Song, J.; Jiang, B.; Pei, F.; Chen, B.; Yang, X.; Liu, G.; Hu, Z. Epigallocatechin-3-gallate protects against cisplatin nephrotoxicity by inhibiting the apoptosis in mouse. Int. J. Clin. Exp. Pathol. 2014, 7, 4607-4616.

58. Khan, S.A.; Priyamvada, S.; Khan, W.; Khan, S.; Farooq, N.; Yusufi, A.N.K. Studies on the protective effect of green tea against cisplatin induced nephrotoxicity. Pharmacol. Res. 2009, 60, 382-391. [CrossRef]

59. Sun, C.; Zhang, H.; Ma, X.; Zhou, X.; Gan, L.; Liu, Y.; Wang, Z. Isoliquiritigenin Enhances Radiosensitivity of HepG2 Cells via Disturbance of Redox Status. Cell Biochem. Biophys. 2013, 65, 433-444. [CrossRef]

60. Bhakta-Guha, D.; Efferth, T. Hormesis: Decoding Two Sides of the Same Coin. Pharmaceuticals 2015, 8, 865-883. [CrossRef]

61. Cox, L.A. (Tony) Hormesis for Fine Particulate Matter (PM 2.5). Dose-Response 2012, 10. [CrossRef]

62. Cybulsky, A.V. Endoplasmic reticulum stress, the unfolded protein response and autophagy in kidney diseases. Nat. Rev. Nephrol. 2017, 13, 681-696. [CrossRef]

63. Dufey, E.; Sepúlveda, D.; Rojas-Rivera, D.; Hetz, C. Cellular Mechanisms of Endoplasmic Reticulum Stress Signaling in Health and Disease. 1. An overview. Am. J. Physiol. Cell Physiol. 2014, 307, C582-C594. [CrossRef]

64. Hiramatsu, N.; Chiang, W.-C.; Kurt, T.D.; Sigurdson, C.J.; Lin, J.H. Multiple Mechanisms of Unfolded Protein Response-Induced Cell Death. Am. J. Pathol. 2015, 185, 1800-1808. [CrossRef] [PubMed]

65. Urra, H.; Dufey, E.; Lisbona, F.; Rojas-Rivera, D.; Hetz, C. When ER stress reaches a dead end. Biochim. Biophys. Acta (BBA) Mol. Cell Res. 2013, 1833, 3507-3517. [CrossRef]

66. Bedard, K.; MacDonald, N.; Collins, J.; Cribb, A. Cytoprotection Following Endoplasmic Reticulum Stress Protein Induction in Continuous Cell Lines. Basic Clin. Pharmacol. Toxicol. 2004, 94, 124-131. [CrossRef] [PubMed]

67. Prachasilchai, W.; Sonoda, H.; Yokota-Ikeda, N.; Oshikawa, S.; Aikawa, C.; Uchida, K.; Ito, K.; Kudo, T.; Imaizumi, K.; Ikeda, M. A protective role of unfolded protein response in mouse ischemic acute kidney injury. Eur. J. Pharmacol. 2008, 592, 138-145. [CrossRef] [PubMed] 
68. Xu, Y.; Guo, M.; Jiang, W.; Dong, H.; Han, Y.; An, X.F.; Zhang, J. Endoplasmic reticulum stress and its effects on renal tubular cells apoptosis in ischemic acute kidney injury. Ren. Fail. 2016, 38, 831-837. [CrossRef] [PubMed]

69. Yan, M.; Shu, S.; Guo, C.; Tang, C.; Dong, Z. Endoplasmic reticulum stress in ischemic and nephrotoxic acute kidney injury. Ann. Med. 2018, 50, 381-390. [CrossRef]

70. Cao, S.S.; Kaufman, R.J. Targeting endoplasmic reticulum stress in metabolic disease. Expert Opin. Ther. Targets 2013, 17, 437-448. [CrossRef]

71. Halliwell, B. Biochemistry of oxidative stress. Biochem. Soc. Trans. 2007, 35, 1147-1150. [CrossRef] [PubMed]

72. Small, D.M.; Coombes, J.S.; Bennett, N.; Johnson, D.W.; Gobe, G.C. Oxidative stress, anti-oxidant therapies and chronic kidney disease: Oxidative stress and CKD. Nephrology 2012, 17, 311-321. [CrossRef] [PubMed]

73. Bhandary, B.; Marahatta, A.; Kim, H.-R.; Chae, H.-J. An Involvement of Oxidative Stress in Endoplasmic Reticulum Stress and Its Associated Diseases. IJMS 2012, 14, 434-456. [CrossRef] [PubMed]

74. Goligorsky, M.S. Oxidative Stress and the Kidney: Riding on the Curve of Hormesis. Antioxid. Redox Signal. 2016, 25, 117-118. [CrossRef] [PubMed]

75. Mailloux, R.J.; Jin, X.; Willmore, W.G. Redox regulation of mitochondrial function with emphasis on cysteine oxidation reactions. Redox Biol. 2014, 2, 123-139. [CrossRef]

76. Ursini, F.; Maiorino, M.; Forman, H.J. Redox homeostasis: The Golden Mean of healthy living. Redox Biol. 2016, 8, 205-215. [CrossRef]

77. Xiong, Y.; Uys, J.D.; Tew, K.D.; Townsend, D.M. S-Glutathionylation: From Molecular Mechanisms to Health Outcomes. Antioxid. Redox Signal. 2011, 15, 233-270. [CrossRef]

78. Haynes, C.M.; Titus, E.A.; Cooper, A.A. Degradation of Misfolded Proteins Prevents ER-Derived Oxidative Stress and Cell Death. Mol. Cell 2004, 15, 767-776. [CrossRef]

79. Townsend, D.M. Metabolism of Cisplatin to a Nephrotoxin in Proximal Tubule Cells. J. Am. Soc. Nephrol. 2003, 14, 1-10. [CrossRef]

80. Birk, J.; Meyer, M.; Aller, I.; Hansen, H.G.; Odermatt, A.; Dick, T.P.; Meyer, A.J.; Appenzeller-Herzog, C. Endoplasmic reticulum: Reduced and oxidized glutathione revisited. J. Cell Sci. 2013, 126, 1604-1617. [CrossRef]

81. Ognjanović, B.I.; Djordjević, N.Z.; Matić, M.M.; Obradović, J.M.; Mladenović, J.M.; Štajn, A.Š.; Saičić, Z.S. Lipid Peroxidative Damage on Cisplatin Exposure and Alterations in Antioxidant Defense System in Rat Kidneys: A Possible Protective Effect of Selenium. IJMS 2012, 13, 1790-1803. [CrossRef] [PubMed]

82. Uzilday, B.; Ozgur, R.; Sekmen, A.H.; Turkan, I. Endoplasmic reticulum stress regulates glutathione metabolism and activities of glutathione related enzymes in Arabidopsis. Funct. Plant. Biol. 2018, 45, 284. [CrossRef] [PubMed]

83. Zaazaa, A.M.; Motelp, B.A.A.E.; Aniss, N.N.D. Potential Protective Role of Rutin and Alpha-lipoic Acid Against Cisplatin-induced Nephrotoxicity in Rats. Pak. J. Biol. Sci. 2019, 22, 361-371. [CrossRef]

84. Cullinan, S.B.; Zhang, D.; Hannink, M.; Arvisais, E.; Kaufman, R.J.; Diehl, J.A. Nrf2 Is a Direct PERK Substrate and Effector of PERK-Dependent Cell Survival. MCB 2003, 23, 7198-7209. [CrossRef]

85. Huang, Y.; Li, W.; Su, Z.; Kong, A.N.T. The complexity of the Nrf2 pathway: Beyond the antioxidant response. J. Nutr. Biochem. 2015, 26, 1401-1413. [CrossRef] [PubMed]

86. Zhu, Y.; Zheng, Z.; Hu, S.; Ru, X.; Fan, Z.; Qiu, L.; Zhang, Y. Unification of Opposites between Two Antioxidant Transcription Factors Nrf1 and Nrf2 in Mediating Distinct Cellular Responses to the Endoplasmic Reticulum Stressor Tunicamycin. Antioxidants 2019, 9, 4. [CrossRef] [PubMed]

87. Thongnuanjan, P.; Soodvilai, S.; Chatsudthipong, V.; Soodvilai, S. Fenofibrate reduces cisplatin-induced apoptosis of renal proximal tubular cells via inhibition of JNK and p38 pathways. J. Toxicol. Sci. 2016, 41, 339-349. [CrossRef]

88. Clarke, J.M.; Gillings, M.R.; Altavilla, N.; Beattie, A.J. Potential problems with fluorescein diacetate assays of cell viability when testing natural products for antimicrobial activity. J. Microbiol. Methods 2001, 46, 261-267. [CrossRef]

89. Bradford, M.M. A rapid and sensitive method for the quantitation of microgram quantities of protein utilizing the principle of protein-dye binding. Anal. Biochem. 1976, 72, 248-254. [CrossRef]

90. Rahman, I.; Kode, A.; Biswas, S.K. Assay for quantitative determination of glutathione and glutathione disulfide levels using enzymatic recycling method. Nat. Protoc. 2006, 1, 3159-3165. [CrossRef] 
91. Ellman, G.L. Tissue sulfhydryl groups. Arch. Biochem. Biophys. 1959, 82, 70-77. [CrossRef]

92. Carlberg, I.; Mannervik, B. Purification and characterization of the flavoenzyme glutathione reductase from rat liver. J. Biol. Chem. 1975, 250, 5475-5480. [PubMed]

Sample Availability: Samples of the compounds are not available from the authors.

(C) 2020 by the authors. Licensee MDPI, Basel, Switzerland. This article is an open access article distributed under the terms and conditions of the Creative Commons Attribution (CC BY) license (http://creativecommons.org/licenses/by/4.0/). 